\title{
Effects of Syntactic Complexity and Sentence Repetition on Sentence Comprehension in Patients with Dementia of Alzheimer's Type
}

\author{
Hyunjoo Choi, Bongwon Yi \\ Department of Communication Disorders, Korea Nazarene University, Cheonan, Korea
}

Correspondence: Hyunjoo Choi, $\mathrm{PhD}$ Department of Communication Disorders, Korea Nazarene University, 48 Wolbong-ro, Seobuk-gu, Cheonan 31172, Korea

Tel: $+82-41-570-1677$

Fax: +82-41-570-7846

E-mail: hjchoi@kornu.ac.kr

Received: October 5, 2019

Revised: November 15, 2019

Accepted: November 28, 2019
Objectives: Although various strategies have been developed to improve auditory sentence comprehension in patients with dementia of Alzheimer's type (DAT), there is a lack of clinical validation of their effectiveness. The purpose of this study was to investigate the effects of syntactic complexity and sentence repetition on sentence comprehension in patients with DAT and elderly adults. Methods: Thirty elderly adults and 30 patients with DAT participated in this study. The task used a token test, and sentences was presented once or twice using the Pratt program. Results: First, the differences according to group, syntactic complexity and sentence repetition in sentence comprehension were significant. Second, an effect of sentence repetition on the total score was found in section 1-3 composed of 4-7 syntactic words, but was not found in section 4 composed of 6-18 syntactic words and consisting of sentences with different syntactic complexity in both groups. Third, in the case of the elderly adults, a significant correlation between the total score of the token test and sentence comprehension ability and the repetition of sentences was shown only in section 4 and the total score; whereas in the DAT patient group, a significant correlation in sentence comprehension ability as seen from the results of the total score of the token test and sentence repetition was found in all sections and total scores. Conclusion: These results suggest that the effects of sentence repetition on sentence comprehension in patients with DAT differ depending on the syntactic complexity.

Keywords: Syntactic complexity, Sentence repetition, Sentence comprehension, Dementia of Alzheimer's type
알츠하이머형 치매(dementia of Alzheimer's type, DAT)는 기억 장애를 중심으로 하는 진행성 인지기능장애로, 치매를 일으키는 가장 일반적인 원인질환이다(McKhann et al., 1984). DAT 환자의 기억 및 인지기능 장애는 질환 초기부터 타인과의 의사소통 및 상 호작용에 부정적인 영향을 미치며, 환자와의 의사소통 실패는 가 족 및 보호자의 좌절과 부담을 초래한다(Lubinski, 1991). Alzheimer's Disease and Related Disorders Association (1990)의 많은 전문 가들은 DAT 환자와의 의사소통 상황에서 청각적 이해력을 촉진 시키기 위해서는 짧고 구문적으로 간단한 문장을 선택하고 문장 을 반복하여 제시하는 방법을 사용할 것을 권고한다(Orange \& Colton-Hudson, 1998). 짧고 구문적으로 간단한 문장을 사용하는
전략은 문장을 듣고 이해하기 위한 작업기억(working memory)의 요구를 최소화하는 효과가 있으며, 반복하여 문장을 제시하는 전 략은 문장 다시 듣기를 통하여 기억흔적(memory traces)을 강화시 켜 한 번 들었을 때 놓친 부분을 복원해 주는 효과가 있다(Small, Kemper, \& Lyons, 1997). 위와 같은 임상적인 권고는 지금도 널리 사용되고 있으며, 이 두 가지 전략의 효과는 다양한 연구들에 의해 다뤼져 왔다.

$\mathrm{DAT}$ 환자의 문장 길이 및 구문적 복잡성에 따른 청각적 문장이 해 능력의 차이는 여러 연구에서 입증되었다(Choi, 2019; Rochon, Waters, \& Caplan, 1994; Small, Kempler, \& Andersen, 1991). Choi (2019)의 연구에서는 토큰테스트(token test)의 문항을 사용한 청 
각적 문장이해 과제에서 DAT 환자의 경우 문장의 길이가 길고 구 문적 복잡성이 증가할수록 문장이해 수행이 저하되었으며, 이러한 저하 양상은 정상적인 노화로 인한 일반노인의 청각적 문장이해 능 력 손상에 비해 더 두드러지는 것으로 나타났다. 또한, 문장-그림매 칭 과제를 사용한 연구들(Rochon et al., 1994; Small et al., 1991)에 서는 짧고 간단한 문장에서 DAT 환자들의 청각적 문장이해 능력 이 향상되었으며, 문장이해 능력은 작업기억과 유의한 상관이 있었 다고 보고하였다(Small et al., 1991). 이렇듯 길이가 짧고 구문적으 로도 간단한 문장에서 DAT 환자의 청각적 문장이해 수행이 향상 되는 이유를 Bayles와 Tomoeda (2007)는 청각적으로 제시되는 문 장의 명제(proposition) 수와 관련하여 설명하였다. 명제가 많을수 록 청자는 문장 안에 포함된 메시지를 해석하기 위해 더 많은 인지 적 자원을 필요로 하게 되며, 다양한 인지기능장애를 가진 DAT 환 자의 경우 명제의 수가 제한된, 짧고 구문적으로도 간단한 문장에 서 청각적 문장이해 능력이 더 양호함을 알 수 있다. 또한, DAT 환 자의 경우 기억을 위한 보유량(span)의 제한을 보이며 중앙집행처 리(central executive process) 능력이 손상되어 길고 구문적으로 복 잡한 문장이해에 제약을 보이는 것으로 알려져있다(Rochon, Waters, \& Caplan, 2000).

$\mathrm{DAT}$ 환자의 청각적 이해력을 향상시키기 위한 전략으로 문장 전체나 일부 단어를 반복하는 방법이 권고되어 왔지만, 관련 연구 는 제한적이며 반복 전략이 실제로 DAT 환자의 문장이해 능력을 향상시키는지에 대한 결론도 명확하지는 않다. 반복과 관련된 임상 적 권고사항은 망각이 DAT 환자의 가장 중요한 증상이며, 많은 DAT 환자들이 짧은 시간 후에도 이전의 자극을 재생(recall)시키 지 못하기 때문에 가족이나 보호자는 입력된 자극을 지속적으로 상기시키기 위한 방법으로 문장을 반복적으로 제시해야함을 강조 한다(Morris \& Baddeley, 1988). DAT 환자를 대상으로 축어적(verbatim) 반복이 문장이해에 미치는 영향을 알아본 Small 등(1997) 에 따르면, 제시된 문장을 간략화한 형태의 반복이 DAT 환자들의 문장이해 능력을 향상시켰으며, 이러한 효과는 구문적으로 복잡 한 문장에서도 증명되었다. 비록 DAT 환자를 대상으로 한 연구는 아니지만 문장 반복이 청각적 이해력을 높이고, 반복해서 문장을 들었을 때 이해를 위한 반응시간이 단축된다는 이른바 '반복효과 (repetition effect)'는 여러 연구에서 입증되었다. 관련된 연구를 살 펴보면, 우선 학령기 아동을 대상으로 한 Cervantes와 Gainer (1992) 의 연구에서는 문장을 두 번 들려주었을 때 아동들의 문장이해 능 력이 향상되었으며, 반복효과는 구문적 복잡성과 관계없이 모든 문장에서 나타났다. 일반성인을 대상으로 양전자방출단층촬영 (positron emission tomography, PET)을 이용하여 단어 반복에 따
른 문장이해 능력 향상과 뇌혈류 사이의 관련성을 살펴본 연구에 서는 단어 반복 시 좌측 조가비핵(putamen)과 우측 미상핵(caudate)의 혈류가 증가하고, 좌측 후측두엽의 혈류가 감소하는 것으 로 나타났다(Stowe et al., 1999). 즉, 해부학적으로는 반복을 통하여 기억흔적(memory trace)은 증가하며, 자극의 입력을 위한 처리 과 정의 요구는 감소하는 것으로 생각해볼 수 있다. 이러한 반복효과 는 종종 누적구조프라이밍(cumulative structural priming) 작용 으로도 설명되는데, 반복을 통하여 정보가 누적되고 앞서 들은 정 보가 구조적 프라이밍으로 작용하여 언어이해 능력을 높이고(Fine \& Jaeger, 2016) 이해 속도를 가속화시키는 것으로 알려져있다(Myslín \& Levy, 2016). 또한, 문장 반복 제시에 따른 시연(rehearsal) 활 성화 및 입력강화(input enhancement)로 인한 단기기억 및 작업기 억의 활성화 역시 문장이해에 긍정적인 영향을 미치는 것으로 생 각해볼 수 있다. 즉, 청각적으로 입력된 정보를 마음 속으로 되내이 는 내현적 시연(subvocal rehearsal)(Baddeley, 2000)과, 동일한 청 각 정보를 반복적으로 들려주는 청각적 입력강화(auditory input enhancement)가 단기기억 및 작업기억을 활성화시키며 이러한 활 성화로 인해 문장이해 능력이 향상될 수 있다(Kim \& Ha, 2019). 반 복에 의한 이해 능력의 향상은 담화(discourse) 과제에서도 나타나 는데 아동을 대상으로 반복적으로 이야기를 들려준 경우 이야기 이해의 수행이 높았으며(Mares, 2006), 일반노인을 대상으로 한 연 구에서도 반복이 문맥(context)에 대한 정보를 채워 주기 때문에 이 해력을 향상시킨다고 보고되었다(Pichora-Fuller, 2008).

$\mathrm{DAT}$ 환자의 이해력 향상을 위하여 어떤 문장 제시 전략을 사용 할 것인가는 임상적으로 매우 중요한 이슈이다. 임상적 관점에서 $\mathrm{DAT}$ 환자의 문장이해 어려움의 원인이 주의력 혹은 기억력 결핍 으로 인한 것이라면 문장을 반복적으로 제시하는 전략이 효과적 일 것이며, 구문적 언어 결함이 동반된 경우라면 문장을 단순화하 고 문장 입력의 양식(modality)을 수정하는 것이 유용할 것이다 (Kempler, Almor, Tyler, Andersen, \& MacDonald, 1998). 그러나 DAT 환자의 문장이해 능력의 제한은 기억력, 주의력 및 구문적 언 어 결함이 동시에 내재할 가능성이 높으며, 그렇다면 문장의 길이 나 구문적 복잡성에 따라 문장 반복효과가 상이하게 나타날 수 있 을 것이다. 따라서 DAT 환자의 문장 반복에 따른 문장이해 능력의 변화를 알아보기 위해서는 다양한 길이와 구문적 복잡성으로 구 성된 문장에서의 반복효과를 비교하는 작업이 필요하다. 그러나 DAT 환자의 반복에 따른 문장이해 능력을 살펴본 연구는 대단히 제한적이며, 관련된 기존 연구(Small et al., 1997)에서는 문장 전체 를 반복한 것이 아니라 원래의 문장을 간략화하여 반복하는 축약 적 반복 방법을 사용하였기 때문에 DAT 환자들의 문장이해 능력 
의 향상이 문장의 간략화로 인한 효과인지, 반복의 효과인지를 구 별하기 어렵다. 따라서 본 연구에서는 다양한 문장 길이와 구문적 복잡성을 가진 문장을 반복해서 제시하는 방법이 DAT 환자의 문 장이해 능력에 어떠한 영향을 미치는지 살펴보는 것을 목적으로 하였다. 구체적인 연구문제는 다음과 같다. 첫째, 일반노인과 DAT 환자 집단을 대상으로 집단, 구문적 복잡성, 문장 반복에 따른 문장 이해 능력의 차이를 알아본다. 둘째, 두 집단의 문장 반복에 따른 문 장이해 능력 향상의 효과가 문장 길이 및 구문적 복잡성에 따라 어 떻게 달라지는지 알아본다. 마지막으로 토큰테스트의 총점과 문장 반복 시 단원별 문장이해 점수 및 총점 사이의 관련성을 살펴본다.

\section{연구방법}

\section{연구 대상}

본 연구는 DAT 환자 30 명과 일반노인 30 명을 대상으로 하였다. 연구 대상자의 구체적인 선정기준은 다음과 같다. DAT 환자는 신 경과 혹은 정신건강의학과 전문의에 의해 probable DAT 로 진단받 은 환자로, NINCDS-ADRDA (National Institute of Neurological and Communicative Disorders and Stroke and Alzheimer's Disease and Related Disorders Association; McKhann et al., 1984)의 진단기준을 충족하는 대상자로 하였다. 중등도(severity) 기준은 Clinical Dementia Rating (CDR; Morris, 1993)의 총점이 2 이하인 경도(mild) 혹은 중등도(moderate) DAT 환자들로 제한하였다. 또 한 과제를 수행하는 데 요구되는 시지각, 청지각에 문제가 없는 환 자들로 선정하였으며, 선정된 38 명의 대상자 중 검사 중단 후 추후 검사 진행에 문제가 있거나 중간에 검사를 거부하는 등의 문제로 제외된 환자는 8 명이었다.

일반노인은 65세 이상으로 한국판 간이정신상태검사(Korean version-Mini Mental State Examination, K-MMSE; Kang, 2006) 의 정상 규준에 속하며(1 SD 이상), 본인의 보고에 의해 신경학적 질환력이 없고, 노인우울척도(Geriatric Depression Scale, GDS; Jung et al., 1997) 점수가 18점 이하인 대상자를 선정하였다. DAT 환자와 일반노인 집단의 연령, 교육년수, K-MMSE 점수에 차이가 있는지 알아보기 위하여 독립표본 $t$-검정을 실시한 결과 연령 $(t=$ $-1.254, p>.05)$ 및 교육년수 $(t=.802, p>.05)$ 에는 집단 간 유의한 차 이가 나타나지 않았으나 K-MMSE $(t=13.144, p<.001)$ 에서는 일반 노인 집단의 점수가 DAT 환자 집단에 비해 유의하게 높은 것으로 나타났다. 두 집단의 연령, 교육년수 및 K-MMSE 점수의 기술통계 결과는 Table 1 과 같다.
Table 1. Results of age, education level, and K-MMSE score in healthy elderly adults and DAT group

\begin{tabular}{lcr}
\hline & Healthy elderly adults $(\mathrm{N}=30)$ & DAT $(\mathrm{N}=30)$ \\
\hline Age (yr) & $78.55(3.27)$ & $80.40(6.02)$ \\
Education level (yr) & $5.25(3.35)$ & $4.47(3.40)$ \\
K-MMSE score & $27.85(1.63)$ & $18.40(2.92)$ \\
\hline
\end{tabular}

Values are presented as mean (SD).

DAT = dementia of Alzheimer's type; K-MMSE = Korean version of Mini-Mental State Examination (Kang, 2006).

\section{연구 과제}

문장이해

구문적 복잡성과 문장 반복에 따른 문장이해 능력을 평가하기 위하여 본 연구에서는 아동용 토큰 검사(Token Test for ChildrenSecond Edition, TTFC-2; Chung, Kim, \& Shin, 2008)를 사용하였 다. 토큰테스트는 크기와 색, 모양이 다양한 토큰들을 대상자에게 제시하고 검사자가 불러주는 문장을 듣고 토큰을 조작하는 과제로 DAT 환자들의 문장이해 능력을 평가하는 데 유용한 것으로 알려 져있다(Choi, 2019; Faber-Langendoen et al., 1988; Swihart, Panisset, Becker, Beyer, \& Boiler, 1989). 토큰테스트는 총 4단원이며, 1-3 단원은 내부적으로 문장의 길이와 구조가 동일한 각 10 개씩의 문 항으로 이루어져 있으며, 4 단원은 문장의 길이와 구조가 이질적인 16 개의 문장을 포함한다. 1-3단원의 경우 단원이 증가할수록 문장 의 길이가 점차 증가하도록 구성되어 있다. 문장의 길이는 구문적 복잡성의 일차적인 지표가 될 수 있는데, 그 안에 포함된 어절이나 단어, 형태소와 같은 문법 단위의 수가 증가하기 때문이다. 1 단원은 '큰 파란 동그라미를 만지세요'와 같이 4어절 문장으로, 2단원은 '파 란 동그라미와 하얀 네모를 만지세요'와 같이 5 어절 문장으로, 3 단 원은 '큰 하얀 네모와 작은 파란 네모를 만지세요' 와 같이 7어절의 문장으로 구성되어 있다. 형태소의 수 면에서도 각 단원의 문장 내 형태소는 8 개, 10 개, 14 개와 같이 점차 증가한다. 길이 외에 절이나 문장 성분의 수 등을 이용하여 구문적 복잡성 측정을 정밀화하려 는 연구도 존재하지만(Kim, 2010; Kim, 2016; Nam, 2015), 복잡성 측정 지표에 대한 기준은 서로 일치하지 않는다. 다만 어떤 기준을 따르더라도 각 단원의 구문적 복잡성은 점차 증가되는 양상을 보인 다. Koo, Park, Yi, Lee와 Hwang (2015)은 ‘하얀'과 같은 관형어를 하나의 절로 인정하고 있는데 이에 따르면 관형절의 수는 1 단원은 2 개, 2 단원은 2 개, 3 단원은 4 개이지만, 1 단원과는 달리 2 단원과 3 단 원에는 접속조사로 연결된 문 접속 구조가 나타나므로 결국 구문 적 복잡성의 차이가 있다고 할 수 있다. 반면 한 단어 관형어를 절로 인정하지 않는 분석에서도(Nam, 2015), 2단원과 3단원에는 접속조 사로 연결된 문 접속 구조가 존재하며 3 단원 문장은 관형어가 더 많 
고 ‘하얀 네모'를 다시 '큰'이 수식하는 귀환적(recursive) 계층 구조 를 갖고 있으므로 2 단원 문장에 비해 구문적으로는 더 복잡하다고 할 수 있다. 마지막 4단원은 포함된 문장들의 길이와 복잡성이 균일 하지 않다. 6 어절에서 18 어절에 달하는 문장들이 점진적으로 길이 와 구문적 복잡성이 증가되도록 배열되어 있는데, 일부 문장은 길 이나 포함된 문법 단위의 수가 1-3단원과 유사하였지만 논항의 수 와 같은 다른 통사적 지표가 1-3단원에 비해 더 복잡하게 나타나므 로 1-3단원에 비해서는 구문적 복잡성이 더 큰 문장으로 구성되어 있다고 볼수 있다. 본 연구에서는 1-3단원에 문장 길이와 구조가 같 은 6 문장씩을 추가하여 모든 단원의 문장이 16 개가 되도록 문장 수를 일치시켰다. 4 단원 문항의 예시를 Appendix 1 에 제시하였다.

\section{문장 제시}

토큰테스트의 문장은 음향분석프로그램인 Praat (version 6.0.33) 를 사용하여 조정 후 제시하였다. 우선 말속도의 통제를 위하여 문 장을 녹음한 기존의 연구결과(Choi, 2019; Shin, 2018)를 바탕으로 한국어에서의 보통 말속도인 4.7 음절/초로 말속도를 통일하였다. 다음으로 문장 반복 문항의 경우 역시 Praat를 활용하여 같은 음원 이 두 번 재생되도록 하였다. 전체 문항 중 홀수 문항은 한 번, 짝수 문항은 두 번 제시되는 문항으로 음원을 배열하여 단원별로 한 번 들려주는 문항과 문장 반복 문항이 번갈아 제시되도록 조정하였다.

\section{연구 절차}

본 연구는 나사렛대학교 생명윤리위원회의 승인을 얻어 진행하 였다(No. 17-1019-05). 또한, 연구 대상자들에게 연구의 목적 및 방 법을 설명하고 서면으로 동의를 얻었다. 모든 검사는 조용하고 방 해받지 않는 공간에서 일대일로 진행되었으며, 검사에 대해 자세히 설명한 후 본 검사를 실시하였다. 연구 대상자들에게 Praat를 사용 하여 미리 녹음해 둔 토큰테스트의 문항을 듣고 배열된 토큰을 조 작하도록 하였다. 연구 대상자들의 반응은 즉시 기록하였으며, 단 원별 정답률(\%)을 토큰테스트 점수로 사용하였다.

\section{통계 분석}

본 연구에서는 일반노인과 DAT 환자 집단을 대상으로 구문적 복잡성과 문장 반복에 따른 문장이해 능력의 차이를 알아보기 위 하여 일반노인, DAT 환자 집단을 집단간 요인으로, 구문적 복잡성 (4) $\times$ 문장제시 횟수(2)를 집단 내 요인으로 한 혼합삼원분산분석 (three-way mixed ANOVA)을 실시하였다. 추가적으로 구문적 복 잡성에 따른 수행차이를 알아보기 위하여 Tukey HSD의 방법으로 사후분석을 실시하였다. 다음으로 한 번 들려주었을 때의 토큰테
스트 총점과 문장 반복에 따른 단원별 문장이해 점수 및 총점 사이 의 Pearson적률 상관분석을 실시하였다. 모든 통계분석은 SPSS version 22 프로그램을 사용하였다.

\section{연구결과}

\section{구문적 복잡성과 문장 반복에 따른 문장이해 수행}

일반노인 집단과 DAT 환자 집단의 구문적 복잡성 및 문장 반복 에 따른 문장이해 점수를 Table 2에 제시하였다. 결과를 살펴보면 문장 반복 여부와 관계없이 모든 단원에서 DAT 환자 집단의 문장 이해 수행이 일반노인에 비해 낮았으며, 일반노인 집단, DAT 환자 집단 모두 구문적 복잡성이 증가하면 문장이해 점수가 낮아짐을 알 수 있다. 문장 반복에 따른 효과를 살펴보면 일반노인, DAT 환 자 집단 모두 3 단원까지는 문장 반복으로 인한 문장이해 능력 향상 의 효과가 나타났지만, 구문적 복잡성이 가장 복잡한 4 단원의 경우 문장 반복의 효과가 나타나지 않았다. 또한, 일반노인 집단의 경우 3 단원까지 문장 반복 시 수행률이 $95 \%$ 이상으로 문장 반복으로 인 한 문장이해 능력 향상의 효과가 극명하게 나타났다.

\section{집단 간 구문적 복잡성과 문장 반복에 따른 문장이해 능력의 차이}

일반노인과 DAT 환자 집단의 구문적 복잡성과 문장 반복에 따 른 문장이해 능력의 집단 간 차이를 알아보기 위하여 혼합삼원분 산분석을 실시하였다. 결과를 살펴보면 우선 집단에 대한 주효과가 유의하였다 $(F=27.283, p<.001)$. 다음으로 구문적 복잡성 $(F=285.045$, $p<.001)$ 과 문장 반복 $(F=38.087, p<.001)$ 에 대한 주효과 역시 유

Table 2. Scores for token test according to syntactic complexity and sentence repetition

\begin{tabular}{lccc}
\hline $\begin{array}{c}\text { Number of sentence } \\
\text { presentation }\end{array}$ & $\begin{array}{c}\text { Syntactic } \\
\text { complexity }\end{array}$ & $\begin{array}{c}\text { Healthy elderly } \\
\text { adults group }\end{array}$ & DAT group \\
\hline Once & Section 1 & $88.89(14.07)$ & $85.00(20.69)$ \\
& Section 2 & $85.00(20.69)$ & $77.78(27.10)$ \\
& Section 3 & $78.33(20.13)$ & $51.67(26.75)$ \\
& Section 4 & $47.08(14.19)$ & $28.33(17.66)$ \\
Twice (sentence & Total & $76.36(9.96)$ & $60.70(17.59)$ \\
repetition) & Section 1 & $98.33(5.09)$ & $93.89(11.98)$ \\
& Section 2 & $98.88(4.23)$ & $85.00(17.70)$ \\
& Section 3 & $95.00(10.85)$ & $68.89(23.87)$ \\
& Section 4 & $42.92(13.80)$ & $26.53(18.43)$ \\
& Total & $83.68(5.62)$ & $68.72(12.99)$ \\
\hline
\end{tabular}

Values are presented as mean (SD). DAT $=$ dementia of Alzheimer's type. 

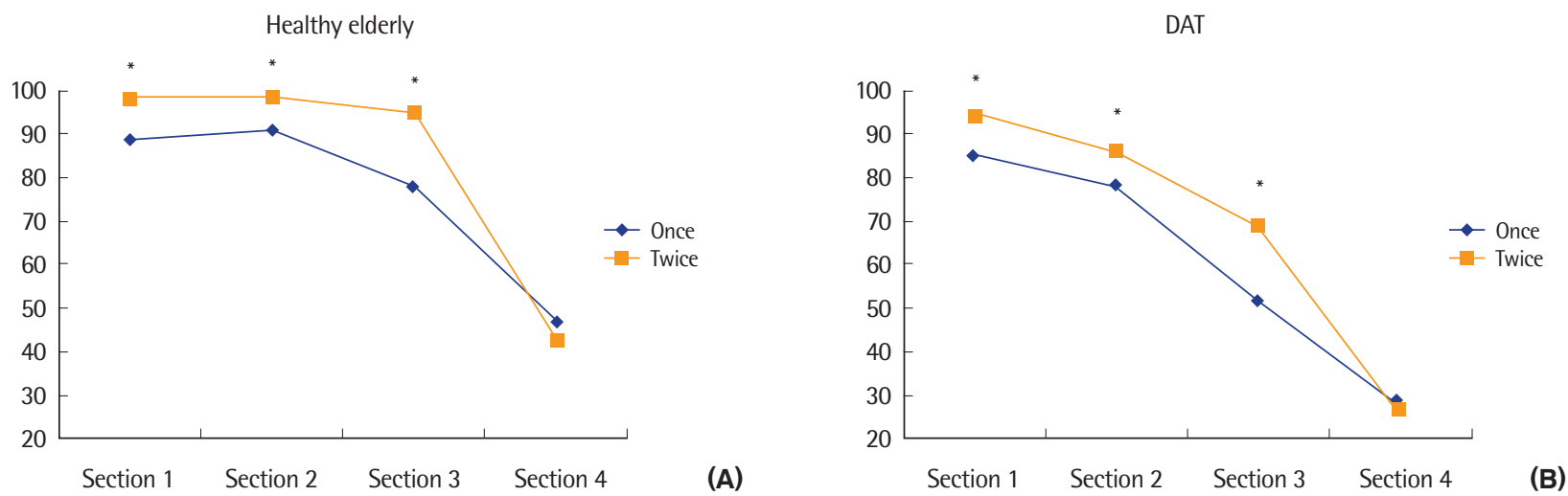

Figure 1. Performances on sentence comprehension according to syntactic complexity and sentence repetition in (A) healthy elderly group and (B) DAT group. DAT $=$ dementia of Alzheimer's type. ${ }^{*} p<.05$.

Table 3. Results of correlation among total score of token test and performance of sentence repetition according to section

\begin{tabular}{llllll}
\hline & Section 1 & Section 2 & Section 3 & Section 4 & Total \\
\hline $\begin{array}{l}\text { Healthy elderly } \\
\text { adults group }\end{array}$ & .307 & .037 & .353 & $.496^{* *}$ & $.551^{* *}$ \\
\begin{tabular}{l} 
DAT group \\
\hline
\end{tabular} & $.597^{* * *}$ & $.500^{* *}$ & $.640^{* * *}$ & $.544^{* * *}$ & $.792^{* * *}$ \\
\hline
\end{tabular}

DAT $=$ dementia of Alzheimer's type.

${ }^{* *} p<.01,{ }^{* * *} p<.001$.

의한 것으로 나타났다. 상호작용효과 분석 결과를 살펴보면 집단 $\times$ 구문적 복잡성 $(F=9.375, p<.001)$, 구문적 복잡성 $\times$ 문장 반복 $(F=16.276, p<.001)$ 의 상호작용효과는 유의한 것으로 나타났으 나, 집단 $\times$ 문장 반복 $(F=.080, p>.05)$, 집단 $\times$ 구문적 복잡성 $\times$ 문 장 반복 $(F=.125, p>.05)$ 의 상호작용 효과는 유의하지 않았다. 마지 막으로 구문적 복잡성에 따른 문장이해 점수의 사후분석을 실시 한 결과 1 단원과 2 단원을 제외한 모든 단원의 문장이해 점수 차이 가 유의한 것으로 나타났다. 집단별 구문적 복잡성과 문장 반복에 따른 문장이해 점수를 Figure 1에 제시하였다.

\section{집단별 토큰테스트 총점과 문장 반복 시 문장이해 능력의 상관}

일반노인과 DAT 환자의 토큰테스트 총점과 문장 반복 시 문장 이해 능력의 상관을 알아보기 위하여 문장을 한 번 제시하였을 때 의 토큰테스트의 총점과 문장 반복 시의 단원별 문장이해 수행과 총점 간의 상관분석을 실시한 결과는 Table 3 에 제시하였다. 결과 를 살펴보면 일반노인의 경우 토큰테스트 총점과 문장 반복 시의 문장이해 능력 간의 유의한 상관은 4 단원과 총점에서만 나타난 반 면, DAT 환자 집단에서는 모든 단원과 총점에서 토큰테스트 총점 과 문장 반복 시의 문장이해 능력 간의 유의한 상관을 보였다.

\section{논의 및 결론}

본 연구에서는 DAT 환자의 청각적 이해력을 향상시키기 위하여 가족이나 보호자들에게 권고되고 있는 전략들 중 문장의 구문적 복잡성을 줄이는 방법과 반복적으로 문장을 제시하는 방법에 대 한 임상적인 효과를 증명하는 것을 목적으로 하였다.

본 연구의 결과를 구체적으로 살펴보면, 일반노인과 DAT 환자 집단 사이의 집단 간 차이, 구문적 복잡성과 문장 반복에 따른 집 단내 차이 모두 통계적으로 유의한 것으로 나타났다. 이 중 집단에 따른 차이를 살펴보면, 구문적 복잡성과 문장 반복의 여부와 관계 없이 DAT환자 집단의 문장이해 수행이 일반노인 집단에 비해 낮 았다. 우선 DAT 환자의 문장이해 능력의 제한은 DAT로 인한 구문 적 문장이해 능력 저하와 연결지어 생각할 수 있다. DAT 환자의 경 우 문장이해에서 의미적 손상과 더불어 구문적 손상도 나타나는 것으로 알려져 있다(de Jager, Hogervorst, Combrinck, \& Budge, 2003; Kim, Sung, \& Jeong, 2012). 그런데 DAT 환자의 구문적 문장 이해 능력의 손상에도 불구하고 문장 길이가 4 어절 정도로 짧고 구 문적 복잡성이 비교적 낮은 1 단원의 경우 일반노인의 수행과 큰 차 이가 나타나지 않았다. 그 이유는 다음과 같이 유추할 수 있다. 첫 째, 본 연구의 과제는 토큰테스트로 사용된 어휘의 친숙도가 매우 높아 DAT로 인한 의미적 문장이해 능력의 제한이 상대적으로 크 지 않았다고 생각할 수 있다(de Jager et al., 2003). 둘째, 경도 DAT 환자의 경우 일상적으로 사용되는 간단한 문장의 이해는 상대적 으로 보존되어 있는 것으로 알려져 있는데(Bickel, Pantel, Eysenbach, \& Schröder, 2000), 본 연구의 대상이 CDR 총점 2점 이하의 DAT 환자만을 대상으로 하였기 때문에 간단한 문장에서의 이해 능력은 어느 정도 유지되었을 것으로 추측할 수 있다. 다음으로 구 
문적 복잡성에 따른 차이를 살펴보면 일반노인 집단, DAT 환자 집 단 모두 구문적 복잡성이 증가하면 문장이해 수행이 낮아짐을 알 수 있다. 이러한 구문적 손상은 작업기억의 제한과 관련이 높은 것 으로 알려져 있는데(Choi, 2019; MacDonald, Almor, Henderson, Kempler, \& Andersen, 2001), 이는 한정된 작업기억 안에서 복잡한 구문을 처리해야 하는 인지적 부담으로 인해 저장용량의 제한이 나타나고, 따라서 작업기억의 손상이 있는 경우 구문적으로 복잡 한 문장을 이해하는 데 부정적인 영향을 미치기 때문인 것으로 생 각할 수 있다(Kim, Sung, \& Yim, 2017). 작업기억 능력의 제한으로 인한 문장이해 능력의 손상은 일반적인 노화(aging)와 DAT의 인 지기능장애 모두에서 나타나는 것으로 알려져 있다. 문장 반복에 따른 효과 또한 유의한 것으로 나타났는데, 일반노인, DAT 집단 모 두 3 단원까지는 문장 반복으로 인한 문장이해 능력 향상의 효과가 나타났지만, 구문적 복잡성이 가장 복잡한 4단원의 경우 문장 반 복의 효과가 나타나지 않았다. 이러한 결과는 일반노인과 DAT 환 자 집단 모두 구문적으로 대단히 복잡한 문장으로 구성된 4단원을 제외하고는 문장 반복 시 문장이해 능력이 유의하게 향상되었다는 것을 의미한다. 이는 문장을 반복적으로 제시하는 전략이 정보 입 력을 위한 처리과정의 요구를 감소시키고, 첫 번째 들었을 때 미처 저장되지 못한 정보에 대한 기억흔적을 강화시키는 효과를 주었기 때문에 문장이해 수행도 좋아진 것으로 생각할 수 있다(Small et al., 1997; Smith, 1968). 그리고 반복해서 문장을 들을 때 첫 번째 입 력된 정보가 구조적 프라이밍으로 작용하여 문장이해의 정반응을 높이고 이해를 위한 시간을 감소시킨다는 기존의 연구결과와도 관 련된 것으로 볼 수 있다(Fine \& Jaeger, 2016). 반복효과는 일반노인 과 DAT 환자 집단 모두에서 나타났으며, 특히 일반노인의 경우 7어 절의 비교적 긴 문장에서도 문장 반복 시 $95 \%$ 이상의 문장이해 정 반응을 보일 정도로 그 효과가 극명하였다.

집단, 구문적 복잡성, 문장 반복 사이의 상호작용효과 분석 결과 를 살펴보면 집단 $\times$ 구문적 복잡성, 구문적 복잡성 $\times$ 문장 반복의 상호작용 효과가 유의한 것으로 나타났다. 그 중 집단과 구문적 복 잡성의 상호작용효과는 일반노인의 경우 3 단원까지의 문장이해 수 행에 비해 6 어절에서 18 어절에 이르는 다양한 길이와 균일하지 않 은 구문적 복잡성을 보이는 4 단원에서의 수행이 갑자기 급격하게 낮아지는 데 반해, DAT 환자는 문장 길이 및 구문적 복잡성이 증 가하는 1-4단원에 걸쳐 점진적으로 수행이 낮아진 결과로 해석할 수 있다. 다음으로 구문적 복잡성과 문장 반복 사이의 상호작용효 과는 일반노인, DAT 환자 모두 3단원까지는 문장 반복으로 인한 문장이해 능력의 향상이 두드러졌으나, 4 단원에서는 문장 반복의 효과가 나타나지 않은 것과 관련이 있는 것으로 여겨진다.
마지막으로 일반노인과 DAT 환자 집단의 토큰테스트 총점과 문 장 반복 시 문장이해 능력의 상관을 알아보기 위하여 한 번 들려주 었을 때의 토큰테스트의 총점과 단원별 문장 반복 시의 문장이해 능력 간 상관분석을 실시한 결과, 일반노인의 경우 토큰테스트 총 점과 문장 반복 시의 문장이해 능력 간 유의한 상관은 4 단원과 총 점에서만 나타난 반면, DAT 환자 집단에서는 모든 단원과 총점에 서 토큰테스트 총점과 문장 반복 시 문장이해 능력 간의 유의한 정 적 상관을 보였다. 특히 DAT 환자 집단에서는 토큰테스트 총점과 문장 반복 시의 총점 간 상관계수는 .8 로 매우 높았다. 우선 두 집단 에서 토큰테스트 총점과 문장 반복 시의 문장이해 능력 사이의 상 관분석 결과가 상이한 이유는 다음과 같이 생각해 볼 수 있다. 첫 째, 일반노인 집단은 앞에서도 언급했듯이 1-3단원의 경우 문장 반 복 시 $95 \%$ 이상의 문장이해 수행을 보일 정도로 반복효과가 뚜렷 하게 나타났다. 일반노인 집단의 이러한 문장 반복 시 문장이해의 높은 수행은 천정효과(ceiling effect)로 작용하여 토큰테스트의 총 점과 유의한 상관이 나타나지 않았다고 여겨진다. 둘째, 검사자가 불러주는 문장을 듣고 기억하여 토큰을 배열하고 조작해야 하는 토큰테스트는 청각적 문장이해 능력뿐만 아니라 대상자의 작업기 억을 민감하게 반영하는 것으로 알려져있다(Cohen-Mimran \& Sapir, 2007). 따라서 문장을 한 번 들려주었을 때 1-3단원까지의 수 행은 대상자의 작업기억 능력에 따라 달라질 수 있을 것이다. 그런 데 일반노인의 경우 문장 반복 시 작업기억의 저하로 인한 수행 저 하를 상쇄할 정도로 반복효과가 극명하였으나, DAT로 인해 병리적 인 작업기억 능력의 손상을 가진 환자의 경우에는 이러한 반복효과 가 다소 제한적으로 나타났다고 볼 수 있다. DAT 환자 집단에서 작 업기억과 반복효과의 상관이 일반노인에 비해 높게 나타난 본 연구 의 결과는 DAT 환자의 경우 작업기억의 개인 차이가 존재하며, 이 러한 차이에 의해 문장이해 능력의 제한이 개인별로 서로 상이함 을 강조한 기존의 연구결과들(Bayles, Tomoeda, \& Trosset, 1992; Choi, 2019; Kempler, Andersen, \& Henderson, 1995)과 맥락을 같 이한다. 한편 4단원의 경우 일반노인과 DAT 환자 모두 토큰테스트 총점과 문장 반복 시의 문장이해 능력 사이의 상관이 유의하게 나 타났다. 4 단원은 비균질적인 문장의 집합으로 구성되어 있으며, 구 문적 복잡성에서도 일관적이지 않은 과제라고 할 수 있다. 가장 짧 은 문장은 6 어절, 가장 긴 문장은 18 어절에 달하며, 구문적 구조 면 에서도 매우 다양한 분포를 보이고 있다. 1 단원에서 3 단원까지는 한 단원 내의 모든 문장이 동일한 통사적 구조를 갖고 있으므로 과 제 수행 시 작업기억과 통사적 분석의 부담이 상대적으로 크지 않 을 것으로 보인다. 일반노인의 경우 반복효과가 크게 나타난 것은 이를 반영하는 것이라고 할 수 있다. 반면 4단원의 문장들은 길이, 
문법 단위의 수, 논항의 수, 문장 성분의 종류 등이 각 문장마다 서 로 다르기 때문에 과제가 제시될 때마다 구문 분석의 부담을 피할 수 없으며, 작업기억 능력에 따라 수행력의 차이가 민감하게 반영 된다고 볼 수 있다. 따라서 1-3단원과 달리 작업기억을 반영하는 토 큰테스트의 총점과 4 단원의 반복 시 문장이해 능력 사이의 상관이 유의하게 나타나는 것으로 해석할 수 있다. 이러한 관련성은 DAT 환자뿐 아니라 상대적으로 작업기억의 손상이 적은 일반노인들에 게서도 나타남을 알 수 있었다.

청각적 문장이해는 타인과의 원활한 의사소통을 위해 필수적인 능력이다. 문장이해를 위해서는 사용된 단어를 빠르게 처리하고 저장된 다른 단어들과 통합하는 능력(Schaie \& Willis, 2010) 및 언 어 이해력 이외의 주의력, 단기기억, 작업기억 등의 인지능력도 요 구된다(Caplan \& Waters, 1999). 따라서 기억력을 포함한 다양한 인지기능장애를 경험하는 DAT 환자의 경우 청각적 이해력의 손상 은 타인과의 의사소통 상황에서 다양한 문제를 야기시킨다. 이러 한 문제를 해결하기 위하여 DAT 환자의 청각적 이해력을 향상시키 기 위한 다양한 전략들이 개발되고 있으며, 환자 가족이나 보호자 들에게 여러 경로로 권고되고 있다. 그 중에서도 간단한 문장을 사 용하고 반복하는 전략은 가장 널리 사용되는 전략 중 하나임에도 불구하고 임상적인 효과 검증은 부족하였다. 본 연구에서는 DAT 환자를 대상으로 다양한 길이와 구문적 복잡성을 가진 문장을 사 용하여 문장 반복으로 인한 문장이해의 효과를 살펴보았다. 본 연 구의 결과를 통하여 DAT 환자들에게 문장을 반복하여 제시하는 전략은 매우 유용함을 알 수 있다. 그러나 이러한 반복효과는 구문 적 복잡성이 상대적으로 낮은 문장에서만 나타났으며, 구문적 복 잡성이 증가하면 이러한 반복효과는 제한적이었다. 이러한 결과는 $\mathrm{DAT}$ 환자에게 문장 길이가 길고 구문적으로 복잡한 문장에 대하 여 반복 전략을 사용할 경우 문장을 간략화하여 반복하는 것이 유 용함을 시사한다.

본 연구는 일반노인과의 비교를 통하여 정상적인 노화와 DAT 질환 사이의 문장이해 능력에 영향을 미치는 구문적 복잡성과 문 장 반복효과 차이를 분석한 점에서 의의를 가진다. 그러나, 다양한 구문적 복잡성에 따른 차이를 분석하지 못한 점, 문장이해 능력과 작업기억 등의 인지기능 사이의 직접적인 관련성을 살펴보지 못한 점 등의 한계를 가진다. 향후에는 이러한 제한점을 보완한 후속연 구가 진행되기를 기대한다.

\section{REFERENCES}

Alzheimer's Disease and Related Disorders Association. (1990). Communi- cating with the Alzheimer's patient. Chicago, IL: The Alzheimer's Association.

Baddeley, A. (2000). The episodic buffer: a new component of working memory? Trends in Cognitive Sciences, 4(11), 417-423.

Bayles, K. A., \& Tomoeda, C. K. (2007). Cognitive-communication disorders of dementia. San Diego, CA: Plural Publication.

Bayles, K. A., Tomoeda, C. K., \& Trosset, M. W. (1992). Relation of linguistic communication abilities of Alzheimer's patients to stage of disease. Brain and Language, 42(4), 454-472.

Bickel, C., Pantel, J., Eysenbach, K., \& Schröder, J. (2000). Syntactic comprehension deficits in Alzheimer's disease. Brain and Language, 71(3), 432-448.

Caplan, D., \& Waters, G. S. (1999). Verbal working memory and sentence comprehension. Behavioral and Brain Sciences, 22(1), 77-94.

Cervantes, R., \& Gainer, G. (1992). The effects of syntactic simplification and repetition on listening comprehension. TESOL Quarterly, 26(4), 767-770.

Choi, H. (2019). Ability of sentence comprehension according to syntactic complexity and speech rate in patients with dementia of Alzheimer's type. Communication Sciences \& Disorders, 24(3), 673-682.

Chung, B. J., Kim, Y. T., \& Shin, M. J. (2008). A pilot study on the development of the Korean-Token Test for Children. Korean Journal of Communication \& Disorders, 13(4), 621-634.

Cohen-Mimran, R., \& Sapir, S. (2007). Deficits in working memory in young adults with reading disabilities. Journal of Communication Disorders, 40(2), 168-183.

de Jager, C. A., Hogervorst, E., Combrinck, M., \& Budge, M. M. (2003). Sensitivity and specificity of neuropsychological tests for mild cognitive impairment, vascular cognitive impairment and Alzheimer's disease. Psychological Medicine, 33(6), 1039-1050.

Faber-Langendoen, K., Morris, J. C., Knesevich, J. W., LaBarge, E., Miller, J. P., \& Berg, L. (1988). Aphasia in senile dementia of the Alzheimer type. Annals of Neurology, 23(4), 365-370.

Fine, A. B., \& Jaeger, T. F. (2016). The role of verb repetition in cumulative structural priming in comprehension. Journal of Experimental Psychology: Learning, Memory, and Cognition, 42(9), 1362-1376.

Jung, I. K., Kwak, D. I., Shin, D. K., Lee, M. S., Lee, H. S., \& Kim, J. Y. (1997). A reliability and validity study of geriatric depression scale. Journal of Korean Neuropsychiatric Association, 36(1), 103-112.

Kang, Y. (2006). A normative study of the Korean-Mini Mental State Examination (K-MMSE) in the elderly. Korean Journal of Psychology: General, 25(2), 1-12. 
Kempler, D., Almor, A., Tyler, L. K., Andersen, E. S., \& MacDonald, M. C. (1998). Sentence comprehension deficits in Alzheimer's disease: a comparison of off-line vs. on-line sentence processing. Brain and Language, 64(3), 297-316.

Kempler, D., Andersen, E. S., \& Henderson, V. W. (1995). Linguistic and attentional contributions to anomia in Alzheimer's disease. Neuropsychiatry, Neuropsychology, \& Behavioral Neurology, 8(1), 33-37.

Kim, J. K., Sung, J. E., \& Jeong, J. H. (2012). Effects of syntactic complexity on sentence comprehension in persons with mild cognitive impairment and dementia of Alzheimer's type. Korean Journal of Communication \& Disorders, $17(2), 338-355$.

Kim, M. J., \& Ha, J. W. (2019). Effects of vocal rehearsal and auditory input enhancement on delayed nonword repetition performance in children with and without speech sound disorders. Communication Sciences \& Disorders, 24(1), 101-116.

Kim, M. K. (2016). The current situation and future tasks on evaluation methodologies of syntactic complexity for multi-cultural learners. Contemporary Society and Multiculture, 6(2), 47-74.

Kim, S. Y., Sung, J. E., \& Yim, D. (2017). Sentence comprehension ability and working memory capacity as a function of syntactic structure and canonicity in 5-and 6-year-old children. Communication Sciences \& Disorders, 22(4), 643-656.

Kim, U. S. (2010). Diversity and complexity of sentence structure. Poetics \& Linguistics, 19, 67-97.

Koo, B., Park, J., Yi, S., Lee, J., \& Hwang, S. (2015). General Korean grammar. Seoul: Jipmoondang.

Lubinski, R. (1991). Dementia and communication. Philadelphia, PA: B. C. Decker.

MacDonald, M. C., Almor, A., Henderson, V. W., Kempler, D., \& Andersen, E. S. (2001). Assessing working memory and language comprehension in Alzheimer's disease. Brain and Language, 78(1), 17-42.

Mares, M. L. (2006). Repetition increases children's comprehension of television content-up to a point. Communication Monographs, 73(2), 216-241.

McKhann, G., Drachman, D., Folstein, M., Katzman, R., Price, D., \& Stadlan, E. M. (1984). Clinical diagnosis of Alzheimer's disease: report of the NINCDSADRDA Work Group under the auspices of Department of Health and Human Services Task Force on Alzheimer's Disease. Neurology, 34(7), 939944.

Morris, J. C. (1993). The Clinical Dementia Rating (CDR): current version and. Neurology, 43(11), 2412-2414.
Morris, R. G., \& Baddeley, A. D. (1988). Primary and working memory functioning in Alzheimer-type dementia. Journal of Clinical and Experimental Neuropsychology, 10(2), 279-296.

Myslín, M., \& Levy, R. (2016). Comprehension priming as rational expectation for repetition: evidence from syntactic processing. Cognition, 147, 2956.

Nam, J. (2015). A study of oral complexity of Korean learner: syntactic complexity and lexical complexity (Doctoral dissertation). Kyung Hee University, Seoul, Korea.

Orange, J. B., \& Colton-Hudson, A. (1998). Enhancing communication in dementia of the Alzheimer's type. Topics in Geriatric Rehabilitation, 14(2), 56-75.

Pichora-Fuller, M. K. (2008). Use of supportive context by younger and older adult listeners: Balancing bottom-up and top-down information processing. International Journal of Audiology, 47(Suppl 2), S72-S82.

Rochon, E., Waters, G. S., \& Caplan, D. (1994). Sentence comprehension in patients with Alzheimer's disease. Brain and Language, 46(2), 329-349.

Rochon, E., Waters, G. S., \& Caplan, D. (2000). The relationship between measures of working memory and sentence comprehension in patients with Alzheimer's disease. Journal of Speech, Language, and Hearing Research, 43(2), 395-413.

Schaie, K. W., \& Willis, S. L. (2010). Handbook of the psychology of aging. San Diego, CA: Academic Press.

Shin, J. (2018). Breath and memory in speech based on quantitative analysis of breath groups and pause units in Korean. Korean Linguistics, 79, 91-116. Small, J. A., Kemper, S., \& Lyons, K. (1997). Sentence comprehension in Alzheimer's disease: effects of grammatical complexity, speech rate, and repetition. Psychology and Aging, 12(1), 3-11.

Small, J., Kempler, D., \& Andersen, E. S. (1991). Syntactic comprehension and attention in Alzheimer's disease. Paper presented at the 44th Annual Scientific Meeting of the Gerontological Society of America, San Francisco, CA. Smith, M. C. (1968). Repetition effect and short-term memory. Journal of Experimental Psychology, 77(3, Pt. 1), 435-439.

Stowe, L. A., Paans, A. M., Wijers, A. A., Zwarts, F., Mulder, G., \& Vaalburg, W. (1999). Sentence comprehension and word repetition: a positron emission tomography investigation. Psychophysiology, 36(6), 786-801.

Swihart, A. A., Panisset, M., Becker, J. T., Beyer, J. R., \& Boiler, F. (1989). The Token Test: validity and diagnostic power in Alzheimer's disease. Developmental Neuropsychology, 5(1), 69-78. 
Hyunjoo Choi, et al. • Sentence Comprehension in DAT

COMMUNICATION SCIENCES\& DISORDERS

Appendix 1. 토큰테스트의 4단원 문항의 예시

\begin{tabular}{ll}
\hline 문항번호 & \multicolumn{1}{c}{ 내용 } \\
\hline 2 & 하얀 네모를 노란 동그라미 뒤에 놓으세요 \\
6 & 네모들은 천천히 그리고 동그라미들은 빨리 만지세요 \\
10 & 노란 동그라미를 만지기 전에, 빨간 네모를 집으세요. \\
14 & 노란 네모의 오른쪽에 있는 네모를 만지는데, 파란 동그라미를 만진 후에 만지세요. \\
\hline
\end{tabular}




\section{국문초록}

\section{알츠하이머형 치매 환자의 문장이해 능력에 구문적 복잡성과 문장 반복이 미치는 영향 최현주 · 이봉원 \\ 나사렛대학교 언어치료학과}

배경 및 목적: 알츠하이머형 치매(demntia of Alzheimer's type, DAT) 환자의 청각적 문장이해 능력을 향상시키기 위한 다양한 전략들 이 개발되어 왔지만, 그 효과에 대한 임상적 검증은 부족하다. 본 연구는 DAT 환자와 일반노인을 대상으로 구문적 복잡성과 문장 반복 이 문장이해 능력에 미치는 영향을 알아보는 것을 목적으로 하였다. 방법: 일반노인 30 명과 DAT환자 30 명이 연구에 참여하였다. 연구 과제는 토큰테스트를 사용하였으며, 단원별 문장을 Pratt program을 이용하여 한 번 혹은 두 번 제시되도록 대상자들에게 들려주었 다. 결과: 첫째, 집단, 구문적 복잡성과 문장 반복에 따른 문장이해 수행에 대한 주효과가 모두 유의한 것으로 나타났다. 둘째, 일반노인, DAT 환자 집단 모두 4-7어절로 구성된 1-3단원 및 총점에서는 문장 반복효과가 나타났으나, 6-18어절에 이르고 서로 상이한 구문으로 구성된 4단원의 경우 문장 반복효과가 나타나지 않았다. 마지막으로, 상관분석 결과 일반노인의 경우 토큰테스트 총점과 문장 반복 시 의 문장이해 능력 간 유의한 상관은 4단원과 총점에서만 나타난 반면, DAT 환자 집단에서는 모든 단원과 총점에서 토큰테스트 총점과 문장 반복 시의 문장이해 능력 간의 유의한 상관을 보였다. 논의 및 결론: 본 연구의 결과는 DAT 환자의 문장 반복이 문장이해 능력에 미치는 영향은 구문적 복잡성에 따라 상이함을 시사한다.

핵심어: 구문적 복잡성, 문장 반복, 문장이해, 알츠하이머형 치매

\section{참고문헌}

강연욱(2006). K-MMSE (Korean-Mini Mental State Examination)의 노인 규준 연구. 한국심리학회지: 일반, 25(2), 1-12.

구본관, 박재연, 이선웅, 이진호, 황선엽(2015). 한국어 문법 총론. 서울: 집문당.

김명광(2016). 다문화 학습자 통사적 복잡성 측정법에 대한 현황과 과제. 현대사회와 다문화, 6(2), 47-74.

김미진, 하지완(2019). 외현적 시연과 청각적 입력 강화가 말소리장애 아동의 지연 비단어 따라말하기 수행력에 미치는 영향. Communication Sci-

ences \& Disorders, 24(1), 101-116.

김신영, 성지은, 임동선(2017). 통사 구조와 어순 규범성이 5-6세 아동의 문장이해능력에 미치는 영향 및 작업기억과의 관계. Communication Sci-

ences \& Disorders, 22(4), 643-656.

김의수(2010). 문장 구조의 다양성과 복잡성. 시학과 언어학, 19, 67-97.

김진경, 성지은, 정지향(2012). 통사적 복잡성에 따른 경도인지장애 환자와알츠하이머성 치매환자의 문장이해능력 비교. 언어청각장애연구, 17(2),

338-355.

남주연(2015). 한국어 학습자의 구어 복잡성 연구: 통사 및 어휘 복잡성을 중심으로. 경희대학교 대학원 박사학위논문.

신지영(2018). 언어수행에서의 호흡과 기억. 한국어학, 79, 91-116.

정부자, 김영태, 신문자(2008). 아동용 토큰 검사의 국내적용 타당화 기초연구. 언어청각장애연구, 13(4), 621-634.

정인과, 곽동일, 신동균, 이민수, 이현수, 김진영(1997). 노인우울척도(Geriatric Depression Scale)의 신뢰도, 타당도 연구. 신경정신의학, 36(1), 103-112. 최현주 (2019). 구문 복잡성과 말속도에 따른 알츠하이머형 치매 환자의 문장이해 능력. Communication Sciences \& Disorders, 24(3), 673-682.

\section{ORCID}

최현주(제1저자, 교신저자, https://orcid.org/0000-0003-4654-3206); 이봉원(공동저자, https://orcid.org/0000-0003-1312-8639) 